\title{
PSORIASIS IN CHILDREN AND ADOLESCENTS: EPIDEMIOLOGICAL STUDY OF 280 PATIENTS FROM MEXICO
}

\author{
Andrea Tovar-Garza ${ }^{1}$, Mayela Meza-Resendiz ${ }^{2}$, Elizabeth Guevara-Gutiérrez ${ }^{2}$, \\ Juan Gabriel Barrientos-García ${ }^{2}$ and Alberto Tlacuilo-Parra ${ }^{3 *}$ \\ ${ }^{1}$ Department of Dermatology, University of Texas Southwestern Medical Center, Dallas, Texas, USA; ${ }^{2}$ Instituto \\ Dermatológico de Jalisco "Dr. José Barba Rubio", Jalisco Ministery of Health, Zapopan, Jal.; 'UMAE Hospital \\ de Pediatría, Centro Médico Nacional de Occidente, Instituto Mexicano del Seguro Social, Guadalajara, Jal. Mexico
}

\begin{abstract}
Background: Psoriasis in children and adolescents has not been well studied in Mexico. Objective: To study the epidemiological characteristics of psoriasis in this age group. Methods: This is a retrospective study in an academic, tertiary care dermatology center from January 1999 to December 2014. We included patients $\leq 18$ years of age, with clinical and histopathological diagnosis of psoriasis. We recorded the following information: gender, age, disease duration, clinical variant, nail involvement, treatment, and family history. Descriptive and inferential statistics were used for analysis. Results: Of 2,491 patients with psoriasis, 280 were $\leq 18$ years of age, resulting in a prevalence of $11 \%$. There was female predominance and the mean age was 11.5 years. Disease duration was $18 \pm 34$ months. Plaque psoriasis was the most common form, comprising 191 cases (68\%). Nail involvement occurred in only 15 patients (5\%). Topical treatment was given to 177 patients (63\%). Only 14 cases (5\%) had a family history of psoriasis. These variables did not differ when children were compared with adolescents, except in those with a shorter disease duration ( $13 \pm 19$ vs. $24 \pm 29$ months; $p=0.0004$ ). Conclusions: We found a higher prevalence of psoriasis than previously published studies in this age group and a lower frequency of nail involvement and family history of psoriasis. (REV INVES CLIN. 2017;69:47-50)
\end{abstract}

Key words: Adolescent. Children. Epidemiology. Pediatric dermatology. Psoriasis.

\section{INTRODUCTION}

Psoriasis is a chronic inflammatory disease of the skin that affects $2-3 \%$ of the global population ${ }^{1}$. Among children and adolescents, the prevalence depends on the population studied. In Germany the prevalence is $0.4 \%^{2}$, whereas in India it is $12.5 \%^{3}$. The prevalence also increases with age, being lower in patients one year old $(0.12 \%)$, but much more common at 18 years of age $(1.2 \%)^{4}$. Despite the frequency of psoriasis, epidemiological studies in this age group are scarce and there is no published data from Mexico. Our objective was to investigate the epidemiological characteristics of psoriasis in Mexican children and adolescents.

Corresponding author:

*Alberto Tlacuilo-Parra

Monte Olimpo, 1413

Col. Independencia

C.P. 44340, Guadalajara, Jal., México

E-mail: albtlacuilo@yahoo.com

Received for publication: 08-12-2016

Accepted for publication: 30-01-2017 


\section{PATIENTS AND METHODS}

We conducted a retrospective study between January 19, 1999 and December 31, 2014 at an academic, tertiary care dermatology center. We collected data from the medical charts and records of the histopathology department at the same center. We included Mexican patients (by birth), age $\leq 18$ and with a clinical and histopathological diagnosis of psoriasis. Patients were classified as children ( 0 - 11 years) or adolescents (12-18 years) ${ }^{5}$. Recorded data included age, gender, disease duration, clinical variant, nail involvement, type of treatment, and family history of psoriasis. For data analysis, we used descriptive statistics such as the average and SD. For comparison of the qualitative variables, we used $\chi^{2}$ or Fisher's exact test and for quantitative variables, Student's $t$-test. Microsoft ${ }^{\circledR}$ Excel and the Epi-Info ${ }^{\circledR}$ statistical program were used for analysis.

\section{RESULTS}

During the 16-year period, we identified 2,491 patients with a clinical and histopathological diagnosis of psoriasis; 280 patients were $\leq 18$ years old, corresponding to a prevalence of $11 \%$ in our institution. Of them, $242(86 \%)$ came from the state of Jalisco, while the remaining $38(14 \%)$ came from the states of Michoacán, Colima, Guanajuato, Zacatecas, Guerrero, Nayarit, Sinaloa, and Aguascalientes. Of the 280 cases, 113 (40\%) were males and 167 (60\%) were females, with a ratio of $1: 1.5$. The mean age at diagnosis was $11 \pm 5$ years (range, 7 months- 18 years). The mean disease duration was $18 \pm 34$ months (range, 7 days-10 years). According to the psoriasis activity and severity index (PASI), a mild form (PASI 0-10) was reported in 193 (69\%) patients and a moderate-to-severe form (PASI > 10) in $87(31 \%)$. Overweight or obesity 6,7 was detected in 118 (42\%) patients.

The frequency of clinical variants is shown in table 1 . The most common clinical variant was plaque psoriasis (68\%). There were no cases of erythroderma. Nail involvement was present only in 15 cases (5\%); nail matrix changes were the most common abnormalities (pitting $73 \%$, onychauxis $13 \%$, leukonychia $7 \%$, and longitudinal grooves $7 \%$ ). Fourteen patients ( $5 \%$ ) had a family history of psoriasis, by first degree in eight (57\%) and second degree in six (43\%). Only two patients
Table 1. Clinical characteristics of psoriasis in 280 Mexican children and adolescents

\begin{tabular}{lc}
\hline Clinical variant $(\mathbf{n}=\mathbf{2 8 0})$ & Number $(\%)$ \\
\hline Plaque & $191(68.0)$ \\
Guttate & $35(12.5)$ \\
Palmar-plantar & $32(11.0)$ \\
Inverse & $12(4.0)$ \\
Pustular & $5(2.0)$ \\
Ungual & $4(1.0)$ \\
Ostraceous & $1(0.5)$ \\
\hline
\end{tabular}

$(0.7 \%)$ had comorbidities: one case of alopecia areata and one case of dermatomyositis.

Topical treatment as monotherapy was prescribed in 177 cases (63\%), systemic in seven ( $2.5 \%$ ), and a combination of both in 63 (22.5\%) patients. Topical medications included keratolytics (salicylic acid or urea) in 94 cases $(34 \%)$, coal tar or anthralin in $91(32.5 \%)$, corticosteroids alone or combined in 89 (32\%), vitamin D analogs alone or combined in 70 (25\%), and calcineurin inhibitors in five (2\%). Systemic medications were dapsone in 35 cases $(12.5 \%)$, antibiotics in $31(11 \%)$, and psoralens in five ( $2 \%)$.

A comparison of clinical variables in children and adolescents is shown in table 2. Plaque psoriasis was the most common type in both groups. Guttate psoriasis was more common in adolescents, whereas inverse psoriasis was more common in children (7\%) compared to adolescents ( $2 \%$ ), although it did not achieve statistical significance. Children had a shorter mean disease duration of $13 \pm 19$ months compared with teenagers $(p=0.0004)$.

\section{DISCUSSION}

The prevalence of psoriasis in Mexican children and adolescents $(11 \%)$ was higher than that reported in Turkish $(3.8 \%)^{8}$ and German $\left(0.4^{2}-0.71 \%^{4}\right)$ populations. In contrast, the frequency of a family history of psoriasis was lower (5\%) compared to the Turkish study $(23 \%)^{8}$. This difference could be explained mainly by the lack of awareness about the disease among family members of our patients and the retrospective nature of our study. Farber, et al. ${ }^{9}$ observed in their follow-up study that during subsequent consultations, patients reported a higher probability of family history. It 
Table 2. Comparison of children and adolescents with psoriasis $(n=280)$

\begin{tabular}{lccc}
\hline Variable & Children $(\mathrm{n}=132)$ & Adolescents $(\mathrm{n}=148)$ & $\mathrm{n}(\%)$ \\
& $\mathrm{n}(\%)$ & $87(59.0)$ & $\mathrm{p}$ \\
\hline Female & $80(61.0)$ & $15 \pm 2$ & $0.73^{*}$ \\
Mean age (years) \pm SD & $7 \pm 3$ & $24 \pm 29$ & $0.0004^{\#}$ \\
Mean disease duration (months) \pm SD & $13 \pm 19$ & $102(69.0)$ & $0.0004^{\#}$ \\
Plaque psoriasis $(\mathrm{n}=191)$ & $89(67.0)$ & $19(13.0)$ & $0.82^{*}$ \\
Guttate psoriasis $(\mathrm{n}=35)$ & $16(12.0)$ & $17(11.0)$ & $0.72^{*}$ \\
Palmar-plantar psoriasis $(\mathrm{n}=32)$ & $15(11.0)$ & $3(2.0)$ & $0.98^{*}$ \\
Inverse psoriasis $(\mathrm{n}=12)$ & $9(7.0)$ & $3(2.0)$ & $0.07^{*}$ \\
Pustular psoriasis $(\mathrm{n}=5)$ & $2(1.5)$ & $3(2.0)$ & $0.68^{\dagger}$ \\
Ungual psoriasis $(\mathrm{n}=4)$ & $1(0.7)$ & $0(0)$ & $0.62^{\dagger}$ \\
Ostraceous psoriasis $(\mathrm{n}=1)$ & $1(0.7)$ & $9(6.0)$ & $0.47^{\dagger}$ \\
Nail involvement $(\mathrm{n}=15)$ & $6(4.5)$ & $8(5.0)$ & $0.59^{*}$ \\
Family history $(\mathrm{n}=14)$ & $6(4.5)$ & $87(59.0)$ & $0.76^{*}$ \\
Topical treatment $(\mathrm{n}=177)$ & $90(68.0)$ & $6(4.0)$ & $0.20^{*}$ \\
Systemic treatment $(\mathrm{n}=7)$ & $1(0.7)$ & $34(23.0)$ & $0.12^{\dagger}$ \\
Combined treatment $(\mathrm{n}=63)$ & $29(22.0)$ & $0.99^{*}$ \\
\hline
\end{tabular}

* $\chi^{2}$ test; ${ }^{\dagger}$ Fisher's exact test; "Student's $t$-test.

is generally accepted that psoriasis is a phenotypically heterogeneous disease, resulting from an interaction with environmental factors and the activation of multiple genes in different kinds of cells, producing proinflammatory citokines ${ }^{10-12}$. It is also known that a family history of psoriasis is not always present.

In line with what has been reported in the literature, we also found a slight predominance of females, with a male:female ratio of $1: 1.5$, similar to studies from China $(1: 1.13)^{13}$, Australia $(1: 1.14)^{14}$ and Germany $(1: 1.25)^{2}$. The mean age at the time of diagnosis was lower than that reported in German patients ( 11 vs. 15 years) ${ }^{4}$.

Plaque psoriasis was the most common variant in our study, similar to the German and Turkish studies, although they reported a lower frequency of $46.3-54.1 \%{ }^{2,8}$. Guttate psoriasis has been reported as the most common variant in this age group ${ }^{15}$; however, it was second to plaque psoriasis in our study. Inverse psoriasis had been noted more often in pre-pubertal children in a Swedish study, and we observed the same results ${ }^{15}$. Nail involvement was not high in our study (5\%), similar to that reported in China (5.6\%); other authors report an $11-39 \%$ prevalence, although there is good agreement that pitting is the most com/mon finding $3,16,17$.

With respect to treatment, previous reports have mentioned topical therapy as the first choice. However, there are no standardized guidelines on the treatment of psoriasis in children or adolescents, and randomized and controlled studies are scarce ${ }^{18}$. In our institution, although the most frequently used treatment was also topical, corticosteroids were not the most frequent medications. Corticosteroids were prescribed in only $32 \%$ of our patients, in contrast with their use in the majority of children in Germany $(72.2 \%)^{2}$ and Turkey $(92 \%)^{8}$. The off-label use of dapsone is due to its anti-inflammatory and immunomodulatory effects; it has merely been employed in case series of psoriasis, with a good response ${ }^{19}$. The use of systemic antibiotics was proportional with the number of patients with guttate psoriasis, likely due to the induction or exacerbation of psoriatic lesions by bacterial toxins ${ }^{20,21}$.

We did not find differences between children and adolescents, except for disease duration, which allows us to infer that the behavior of psoriasis was similar in both age groups. Some of our variables are similar to previous studies, as shown in table 3 . However, the age groups vary between studies and future, more comprehensive studies are required to allow for better comparisons.

To our knowledge, this is the first epidemiological study of psoriasis in children and adolescents done in Mexico. Limitations of our study include the retrospective nature of the study and ascertainment bias since only children referred to our tertiary care center were included. 
Table 3. Comparison of epidemiological studies of pediatric psoriasis

\begin{tabular}{|c|c|c|c|c|c|c|}
\hline Study & Country & $\mathbf{n}$ & $\begin{array}{l}\text { Male: female } \\
\text { ratio }\end{array}$ & $\begin{array}{c}\text { Family } \\
\text { history \% }\end{array}$ & Type \% & $\begin{array}{c}\text { Nail } \\
\text { involvement \% }\end{array}$ \\
\hline Current study & Mexico & 280 & $1: 1.5$ & 5.0 & $\begin{array}{l}\text { Plaque } 68.0 \\
\text { Guttate } 12.5 \\
\text { Palmar-plantar } 11.0\end{array}$ & $\begin{array}{c}5.0 \\
\text { Matrix } 73.0\end{array}$ \\
\hline Moustou, et al. $2014^{16}$ & Greece & 842 & $1: 1$ & 16.7 & $\begin{array}{l}\text { Plaque } 82.1 \\
\text { Inverse } 20.2 \\
\text { Guttate } 7.5\end{array}$ & 11.8 \\
\hline Fan, et al. $2007^{13}$ & China & 277 & $1: 1.13$ & 34.3 & $\begin{array}{l}\text { Plaque } 68.6 \\
\text { Guttate } 28.9 \\
\text { Erythroderma } 1.4\end{array}$ & $\begin{array}{c}5.6 \\
\text { Matrix } 50.0\end{array}$ \\
\hline Seyhan, et al. $2006^{8}$ & Turkey & 61 & $1: 1.6$ & 23.0 & $\begin{array}{l}\text { Plaque } 83.6 \\
\text { Erythroderma } 16.9\end{array}$ & $\begin{array}{c}21.3 \\
\text { Matrix } 53.9\end{array}$ \\
\hline Kumar, et al. $2004^{3}$ & India & 419 & $1: 0.9$ & 4.5 & $\begin{array}{l}\text { Plaque } 60.6 \\
\text { Plantar } 12.8 \\
\text { Guttate } 9.7\end{array}$ & $\begin{array}{c}31.0 \\
\text { Matrix } 67.0\end{array}$ \\
\hline Morris, et al. $2001^{14}$ & Australia & 1,262 & $1: 1.14$ & 71.0 & $\begin{array}{l}\text { Plaque } 34.0 \\
\text { Inverse } 21.6 \\
\text { Guttate } 6.4\end{array}$ & - \\
\hline Nanda, et al. $1990^{17}$ & India & 112 & $1: 0.9$ & 9.8 & $\begin{array}{l}\text { Plaque } 69.6 \\
\text { Guttate } 25.9 \\
\text { Erythroderma } 1.8\end{array}$ & $\begin{array}{c}39.3 \\
\text { Matrix } 76.0\end{array}$ \\
\hline
\end{tabular}

In conclusion, the prevalence of psoriasis in our institute was higher than reported in other countries, although the presence of nail involvement and a family history of psoriasis were lower. The clinical variants we found are similar to those observed in adults, and most patients were treated in a conservative manner with topical medication.

\section{ACKNOWLEDGEMENTS}

We would like to thank Dr. Amit G. Pandya, University of Texas Southwestern Medical Center, Dallas, Texas, for reviewing and editing of the manuscript.

\section{REFERENCES}

1. Gelfand JM, Weinstein R, Porter SB, Neimann AL, Berlin JA, Margolis DJ. Prevalence and treatment of psoriasis in the United Kingdom: a population-based study. Arch Dermatol. 2005;141: $1537-41$.

2. Matusiewicz D, Koerber A, Schadendorf D, Wasem J, Neumann A. Childhood psoriasis-an analysis of German health insurance data. Pediatr Dermatol. 2014;31:8-13.

3. Kumar B, Jain R, Sandhu K, Kaur I, Handa S. Epidemiology of childhood psoriasis: a study of 419 patients from northern India. Int J Dermatol. 2004;43:654-8.

4. Augustin M, Glaeske G, Radtke MA, Christophers E, Reich K, Schäfer I. Epidemiology and comorbidity of psoriasis in children. Br J Dermatol. 2010;162:633-6.

5. Williams K, Thomson D, Seto I, et al. StaR Child Health Group. Standard 6: Age Groups for Pediatric Trials. Pediatrics. 2012;129: 153-60.
6. Obesity and overweight. Center for Disease Control (CDC). Available at: https://www.cdc.gov/ncbddd/spanish/disabilityandhealth/ obesity.html [Accessed 01/12/2017].

7. Obesity and overweight. World Health Organization (WHO). Available at: http://www.who.int/mediacentre/factsheets/fs311/es/ [Accessed 01/12/2017].

8. Seyhan M, Coşkun BK, Sağlam H, Ozcan H, Karincaoğlu Y. Psoriasis in childhood and adolescence: evaluation of demographic and clinical features. Pediatr Int. 2006;48:525-30.

9. Farber EM, Mullen RH, Jacobs AH, Nall L. Infantile psoriasis: a follow up study. Pediatr Dermatol. 1986;3:237-43.

10. Henseler T. The genetics of psoriasis. J Am Acad Dermatol. 1997 37:1-11.

11. Swanbeck G, Inerot A, Martinsson T, et al. Genetic counselling in psoriasis: empirical data on psoriasis among first- degree relatives of 3095 psoriatic probands. Br ] Dermatol 1997:137:939-42.

12. Mahil SK, Capon F, Barker JN. Update on psoriasis immunopathogenesis and targeted immunotherapy. Semin Immunopathol. 2016 38:11-27.

13. Fan X, Xiao FL, Yang S, et al. Childhood psoriasis: a study of 277 patients from China. J Eur Acad Dermatol Venereol. 2007; 21:762-5.

14. Morris A, Rogers M, Fischer G, Williams K. Childhood psoriasis: clinical review of 1262 cases. Pediatr Dermatol. 2001;18:188-98.

15. Lysell J, Tessma M, Nikamo P, Wahlgren CF, Ståhle M. Clinical characterization at onset of childhood psoriasis - a cross sectional study in Sweden. Acta Derm Venereol. 2015;95:457-61.

16. Moustou AE, Kakourou T, Masouri S, Alexopoulos A, Sachlas A, Antoniou C. Childhood and adolescent psoriasis in Greece: a retrospective analysis of 842 patients. Int J Dermatol. 2014;53:1447-53.

17. Nanda A, Kaur S, Kaur I, Kumar B. Childhood psoriasis: an epidemiological survey of 112 patients. Pediatr Dermatol. 1990;7:19-21.

18. Megna M, Napolitano M, Balato A, et al. Psoriasis in children: a review. Curr Pediatr Rev. 2015;11:10-26.

19. Halverstam C, Lebwohl M. Nonstandard and off label therapies for psoriasis. Clin Dermatol. 2008;26:546-53.

20. Balci DD, Duran N, Ozer B, Gunesacar R, Onlen Y, Yenin JZ. High prevalence of Staphylococcus aureus cultivation and superantigen production in patients with psoriasis. Eur J Dermatol. 2009; 19:238-42.

21. Atefi N, Noorbakhsh S, Ghavidel DS, Tabatabaei A, Rezaee M. The rise of staphylococcal super antigens in psoriatic patients: a case-control study. See comment in PubMed Commons belowJundishapur J Microbiol. 2014;7:e9912. 